\title{
Use of superabsorbent polymers in cement-based compounds: a bibliometric analysis
}

\author{
Uso de polímeros superabsorventes em compostos a base de cimento: uma análise bibliométrica \\ Uso de polímeros superabsorbentes en compuestos a base de cemento: un análisis bibliométrico
}

Received: 10/15/2021 | Reviewed: 10/24/2021 |Accept: 10/26/2021| Published: 10/30/2021

\author{
Michel Henry Bacelar de Souza \\ ORCID: https://orcid.org/0000-0001-8327-6181 \\ Universidade Federal de Itajubá, Brasil \\ E-mail: michelhenry@unifei.edu.br \\ Paulo César Gonçalves \\ ORCID: https://orcid.org/0000-0001-7391-9972 \\ Universidade Federal de Itajubá, Brasil \\ E-mail: paulocg9@unifei.edu.br \\ Lucas Ramon Roque Silva \\ ORCID: https://orcid.org/0000-0003-0387-622X \\ Universidade Federal de Itajubá, Brasil \\ E-mail: lucasramonroque@gmail.com \\ Mirian de Lourdes Noronha Motta Melo \\ ORCID: https://orcid.org/0000-0001-9668-7799 \\ Universidade Federal de Itajubá, Brasil \\ E-mail: mirianmottamelo@unifei.edu.br \\ Valquíria Claret dos Santos \\ ORCID: https://orcid.org/0000-0001-7744-3262 \\ Universidade Federal de Itajubá, Brasil \\ E-mail: valquiria@unifei.edu.br
}

\begin{abstract}
Superabsorbent polymers (SAP) have gained the attention of the engineering field for applications in cementitious composites. Recently, many studies have addressed using these materials as an alternative to controlling recurrent pathologies, especially retraction in the hardening stage. This study conducted a literature review in the Scopus and Web of Science databases to identify relevant studies for future research in this area. Analyses were performed using the RStudio software program, where data on the number of publications, the main authors and journals, the most used keywords, and most common countries of publication were analyzed. Furthermore, bibliographic coupling and cocitation analyses were carried out. The results indicate that the most published authors were De Belie, Snoeck and Liu J., and the most cited authors were Jensen, Schrofl and Snoeck. Although Brazil is among the fifteen most published countries, it was not among the most cited, showing lacks in studies. In total, 343 articles were found in the Scopus database and 369 in the Web of Science.
\end{abstract}

Keywords: Superabsorbent polymer; Concrete; Mortar; SAP; Bibliometric analysis.

\section{Resumo}

Os polímeros superabsorventes (SAP) mostram-se promissores no ramo da engenharia quando adicionados em compositos cimentícios. Recentemente, muitos estudos vêm abordando o emprego desses materiais como alternativa para o controle de manifestações patológicas recorrentes, principalmente a retração no estágio endurecido. Esse trabalho apresenta uma revisão bibliométrica nas bases de dados da Scopus e Web of Science acerca do mesmo, com o objetivo de facilitar a localização de estudos relevantes para futuras pesquisas nessa área. Foi realizada uma análise utilizando o software RStudio onde obteve-se os dados de quantidade de publicações, principais autores e periódicos, palavras-chave mais usada e países que mais publicam além de análises de acoplamento bibliográfico e cocitação. Neste contexto, podese ressaltar que os autores que mais publicam são De Belie, Snoeck e Liu J., em contrapartida os mais citados são Jensen, Schrofl e Snoeck, respectivamente. O Brasil, embora esteja entre os quinze países que mais publicam, ele não está entre os que mais são citados, evidenciando uma deficiência dos estudos. No total, foram encontrados 343 artigos na base de dados da Scopus e 369 na Web of Science.

Palavras-chave: Polímero superabsorvente; Concreto; Argamassa; SAP; Análise bibliométrica.

\section{Resumen}

Los polímeros superabsorbentes (SAP) han atraído la atención del campo de la ingeniería para aplicaciones en compuestos cementosos. Recientemente, numerosos estudios han abordado el uso de estos materiales como alternativa al control de patologías recurrentes, especialmente la retracción en la etapa de endurecimiento. Este estudio realizó una revisión de la literatura en las bases de datos Scopus y Web of Science para identificar estudios relevantes para futuras investigaciones en esta área. Los análisis se realizaron mediante el programa informático RStudio, donde se analizaron 
datos sobre el número de publicaciones, los principales autores y revistas, las palabras clave más utilizadas y los países de publicación más habituales. Además, se realizaron análisis de acoplamientos bibliográficos y co-citas. Los resultados indican que los autores más publicados fueron De Belie, Snoeck y Liu J., y los autores más citados fueron Jensen, Schrofl y Snoeck. Si bien Brasil se encuentra entre los quince países más publicados, no estuvo entre los más citados, mostrando carencias en los estudios. En total, se encontraron 343 artículos en la base de datos Scopus y 369 en la Web of Science.

Palabras clave: Polímero superabsorbente; Hormigón; Morir; SAP; Análisis bibliométrico.

\section{Introduction}

Superabsorbent polymers (SAPs) have attracted worldwide attention, and have been widely explored in material technology studies based on cementitious composites for possible applications as internal curing agents, and in the cementitious matrix hydration field (Schröfl et al., 2012). Scientific papers related to this topic over the last decade have shown continuous growth, motivating other researchers to conduct new studies on these possible applications. However, locating published studies in a wide data field is an arduous yet fundamental task in researching and recognizing the current scientific state-of-the-arts on this topic (Treinta et al., 2014; Treinta et al., 1983; Garfield, 2001).

This study sought to develop a theoretical basis for using Superabsorbent Polymers (SAPs) in cement-based compounds to facilitate finding relevant articles and new authors in this area of study. To do this, it was necessary to identify the number of publications over time, the most relevant authors and journals, the countries with the highest number of citations and publications, the most frequently used keywords, the research line segments, and to perform bibliographic coupling and co-citation analyses based on the results, all to point out future trends within the current scientific state-of-the-arts.

\subsection{Superabsorbent polymers}

There are many types of polymers in the market, which are all derived from different chemical compounds. Among the various types, superabsorbent polymers constitute a class of polymers that can absorb and retain large amounts of water. They were first developed in the early 1980s for the personal care industry, more precisely, for use in disposable diapers (Schröfl et al., 2012).

SAP particles can absorb large amounts of liquid without dissolving, and this has a wide range of industrial applications worldwide. More recently, this polymer property has gained the attention of the agricultural sector and the construction industry, the latter which seeks to use SAPs in cement-based composites, given the several advantages pertaining to its super-absorbent properties (Al-Hubboubi et al., 2018).

\subsection{Using SAPs in composite cement materials}

SAPs were applied by the civil construction sector in 2001 to internally cure cement pastes and to control shrinkage (O.M. Jensen \& Hansen, 2001). Considering its potential uses in this sector, there has been a lot of researched developed on this topic, including ways to use it to help reduce pathologies (Shim et al., 2018).

Curing is the step that promotes cement hydration and basically involves controlling temperature and moisture fluctuations. Temperature must be kept constant along the concrete section while strength increases, thus avoiding cracking caused by shrinkage (Bentz et al., 2005; Ribeiro et al., 2021; Rodrigues et al., 2022).

Internal curing consists of adding materials that act as indefinite curing agents during mixing. Internal curing agents can be, for example, light aggregates in special humid conditions, or extra components added to concrete composition, like SAP itself (Ole Mejlhede Jensen \& Lura, 2006).

Autogenous shrinkage occurs when concretes self-dry in low water concentrations during the cement hydration phase. (Snoeck et al., 2012b) states that added SAP in cement-based materials will form water-filled inclusions that gradually release water during the cement hydration process. This method provides additional moisture to the concrete, making cement more efficiently hydrated and reducing autogenous shrinkage. SAP is mixed with concrete and then absorbs part of the mixed water. During the hydration process, the water absorbed by the SAP can be released, promoting hydration and reducing the autogenous shrinkage of the concrete (Manzano et al., 2021; Snoeck et al., 2015).

Several researchers are studying the possibilities and limitations of using SAP in cementitious composites, mainly in mortars and concretes, also to solve pathologies (Snoeck \& De Belie, 2016). Authors like (Guo et al., 2020; Ole Mejlhede Jensen \& Hansen, 2002 ; V. 
Mechtcherine et al., 2018; Schroefl et al., 2012; Snoeck et al., 2012a; Wyrzykowski et al., 2011) believe that SAP-modified cement-based composites hold great promise, and will be widely used in the near future.

\subsection{Contextualization of the literature review}

To more simply identify the most important works, we needed to define the tactics that would be employed in this literature review. Bibliometric techniques began to be developed in the beginning of this century to understand and quantitatively analyze data obtained from scientific publications (Treinta et al., 1983; Grácio, 2016).

Literature reviews allow researchers to highlight any affinities that may exist among their works and the works of others (Sandison, 1989). Similarly, it is necessary to emphasize the importance of bibliographic references as crucial parts of the representative scope for a subject, giving quality, scope, and significance to the research process. Selected articles must reflect current scientific research production trends, and quantitative analyses on these data allows researchers to obtain reliable bases for any given theme (Treinta et al., 2014; Garfield, 2001).

Some definitions for bibliometrics can be found in literature (Vanti, 2002), which state that it is the quantitative and statistical analysis of articles to serve as theoretical foundations for future research, that can be used to map current scientific production on a given topic. Once in possession of data obtained from reliable databases, methods like bibliographic coupling and co-citation can be used to group associated articles within a given theme.

Bibliographic coupling lists study when authors cite one or more articles together, and this technique is directed towards the past, i.e., is retrospective. By contrast, co-citation analysis identifies articles or authors that are cited in common within the same articles, and is a forward-looking analysis (Garfield, 2001; Grácio, 2016). Figure 1 shows the two types of reference analyses, to facilitate understanding their differences.

Figure 1. Bibliographic coupling and co-citation.

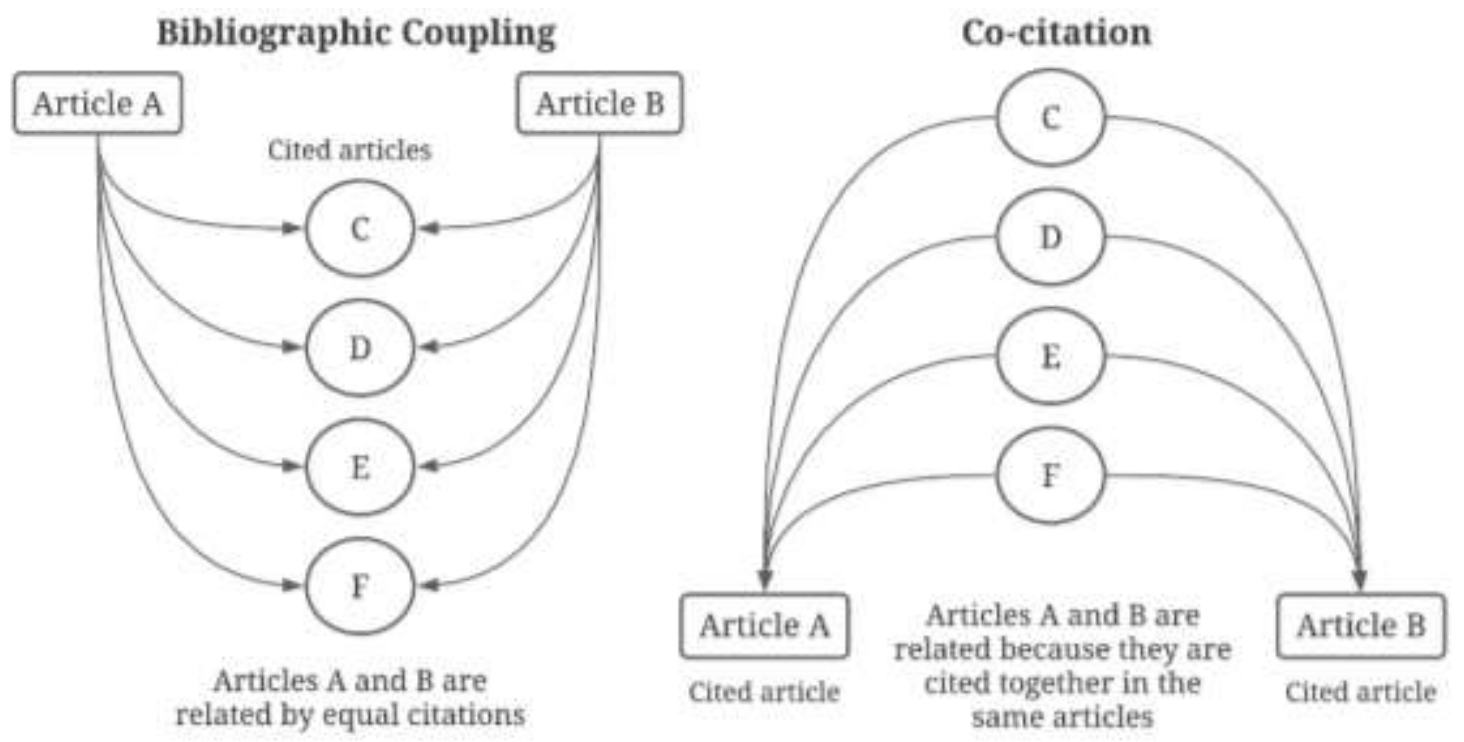

Source: Adapted from Garfield (2001).

\section{Methodology}

The methodology used in this article is based on a methodology used by Treinta et al. (2014), with some modifications. The steps for preforming the searches are presented in this chapter, and the initial steps determine what will be searched for, the subsequent steps, and the data refinement and analysis, as shown in Figure 2. 
Figure 2. Methodology flowchart adapted from (Treinta et al., 2014).

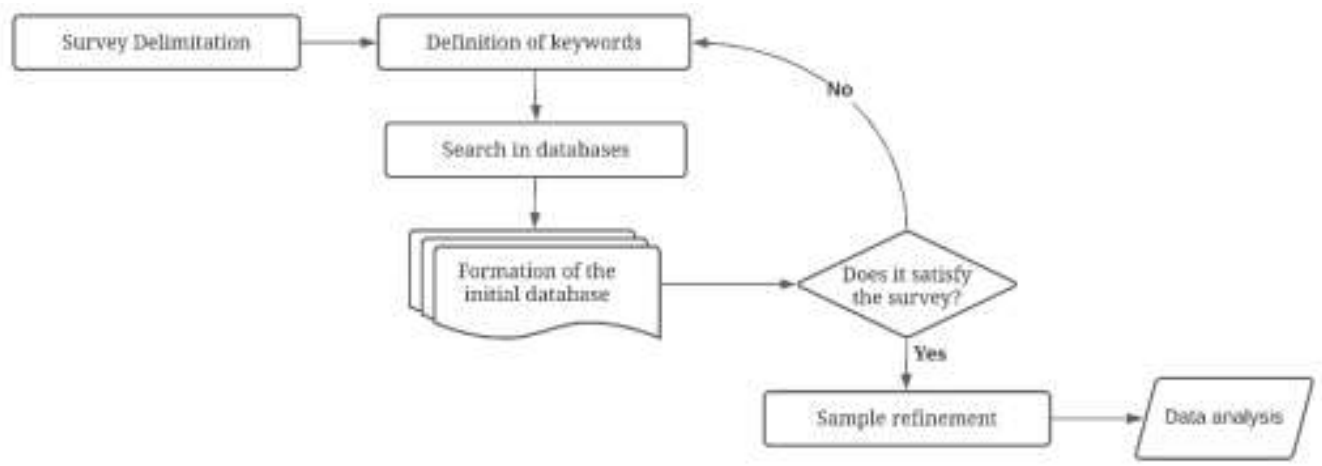

Source: Authors.

\subsection{Defining the research project}

The research processes can be defined first by choosing the databases that will be consulted in the analysis. The Scopus database was chosen, given the large volume of articles related to engineering present there. The other database was the Journal Citation Report (JCR), which evaluates the most important journals in each knowledge area using the Web of Science (WoS) as its base, thus highlighting its importance among databases.

Based on the databases chosen, this research project was defined by the area of knowledge that would be addressed.

\subsection{Defining the keywords}

After defining the databases and the sphere of knowledge for this research project, we chose the reference keywords that would be used. Treinta et al. (2014) highlights the importance of correctly transcribing words during the search phase in databases, since variations may occur. Analyzing the chosen databases, several attempts of keyword combinations were determined in English as: "concrete", "paste", "mortar", "superabsorbent" and "polymer".

\subsection{Searching the databases}

To obtain the greatest number of publications, several different forms of search simulations were carried out in these databases. Search strings were formed where keywords were written in different ways, sometimes separated or placed in quotation marks. We chose to divide the term "superabsorbent polymer" into "superabsorbent" and "polymer", because the number of articles with separate expressions was greater than for the two terms together. Connectives "AND", and the conditional "OR" were used to link the chosen terms. Furthermore, filtering was carried out to arrive at the number of available articles, excluding other types of documents. This process is explained in Table 1, where one can see that the last string used resulted in the most documents.

Table 1. String variations in each database.

\begin{tabular}{lcc}
\hline \multicolumn{1}{c}{ Search Strings (Keywords) } & \multicolumn{2}{c}{ Number of articles } \\
(concrete* AND "superabsorbent polymers") & Scopus & WOS \\
(concrete* AND superabsorbent AND polymer*) & 246 & 270 \\
((concrete* OR mortar*) AND "superabsorbent polymers" ) & 247 & 338 \\
((concrete* OR mortar*) AND superabsorbent AND polymer*) & 294 & 280 \\
((concrete* OR paste*) AND "superabsorbent polymers") & 295 & 353 \\
((concrete* OR paste*) AND superabsorbent AND polymer*) & 297 & 283 \\
((concrete* OR mortar* OR paste*) AND "superabsorbent polymers") & 299 & 359 \\
((concrete* OR mortar* OR paste*) AND superabsorbent AND polymer*) & 341 & 288 \\
\hline
\end{tabular}

Source: Authors. 
It is important to mention that one needs to use elements placed before the strings when searching only the titles, abstracts, and keywords, so that the databases can filter the articles, and these are provided by the databases themselves. Scopus' uses "TITLE-ABS-KEY", and the Web of Science uses "TOPIC:". The search strings are shown in Table 2.

Table 2. Search strings for each database.

\begin{tabular}{cc}
\hline Scopus & $\begin{array}{c}\text { TITLE-ABS-KEY } \\
\\
\text { ( ( concrete* OR mortar* OR paste* }) \text { AND superabsorbent AND polymer* })\end{array}$ \\
\hline Web of & TOPIC: (( concrete* OR mortar* OR paste*) AND superabsorbent AND \\
Science & polymer*) \\
\hline
\end{tabular}

Source: Authors.

\subsection{Forming the initial database}

712 articles were found in the searches carried out in the two databases, from 1997 to 2021.343 articles were found from the Scopus data base, and 369 from the Web of Science database, as shown in Table 3. The documents were extracted in BibTex format, containing technical information on the articles referent to the title, author, journal, country of publication, citations, area of knowledge.

Table 3. Number of articles found in the searches.

\begin{tabular}{ccc}
\hline Base & Search Strings & $\begin{array}{c}\text { Number } \\
\text { of articles }\end{array}$ \\
Scopus & TITLE-ABS-KEY $(($ concrete* OR mortar* OR paste* $)$ & 343 \\
Web of & AND superabsorbent AND polymer* $)$ & \\
Science & TOPIC: $(($ concrete* OR mortar* OR paste* $)$ & 369 \\
\hline
\end{tabular}

Source: Authors.

\subsection{Refining data}

Data refinement is necessary because file extraction from databases can expose articles that present missing information related to the authors, country of origin, journal, or year of publication. A filtering step was performed, where the references of the collected articles from each database were crossed to discard articles with missing data. The Mendeley ${ }^{\mathrm{TM}}$ software program was used to do this. Three (3) of the 343 articles in the Scopus database were discarded. Three (3) of the 369 articles in the Web of Science database were discarded. After this phase, two new BibTex files were generated with the remaining articles.

\subsection{Data analysis}

The analysis of sample data obtained after refinement was done using the RStudio ${ }^{\mathrm{TM}}$ software program, where data on publications like authors, years of publication, country of origin, number of citations, number of publications, and journal information are compiled and organized in order to facilitate the most relevant data extraction. This diagnosis was made separately, first for the Scopus database, and second for the Web of Science database.

Excel $^{\mathrm{TM}}$ was used to merge the results of the two databases and to exclude repeated data, while preserving the one with the greater number for analysis, i.e., if an author was listed as one of the most relevant authors in both databases, the result with the lower publication number was eliminated. This adaptation was made to avoid repetitions in the lists of main results. 


\section{Results}

Based on the analysis carried out in the Rstudio ${ }^{\mathrm{TM}}$ software program, information was obtained from both the Scopus and the Web of Science databases, and these data are presented throughout this chapter. The analysis of the number of articles published in the area throughout history showed an increase in the number of publications in both databases, as shown in Figure 3 . This shows a promising scenario for publications related to this subject, especially since the last 5 years accounted for more than $70 \%$ of all publications throughout history. Most publications were from 2020, when Scopus and WOS registered 72 and 93 publications, respectively. In 2021, despite these surveys having been carried in May 20, both databases registered more than 30 articles, indicating that 2021 will again have many publications.

Figure 3. Annual Scientific Production.

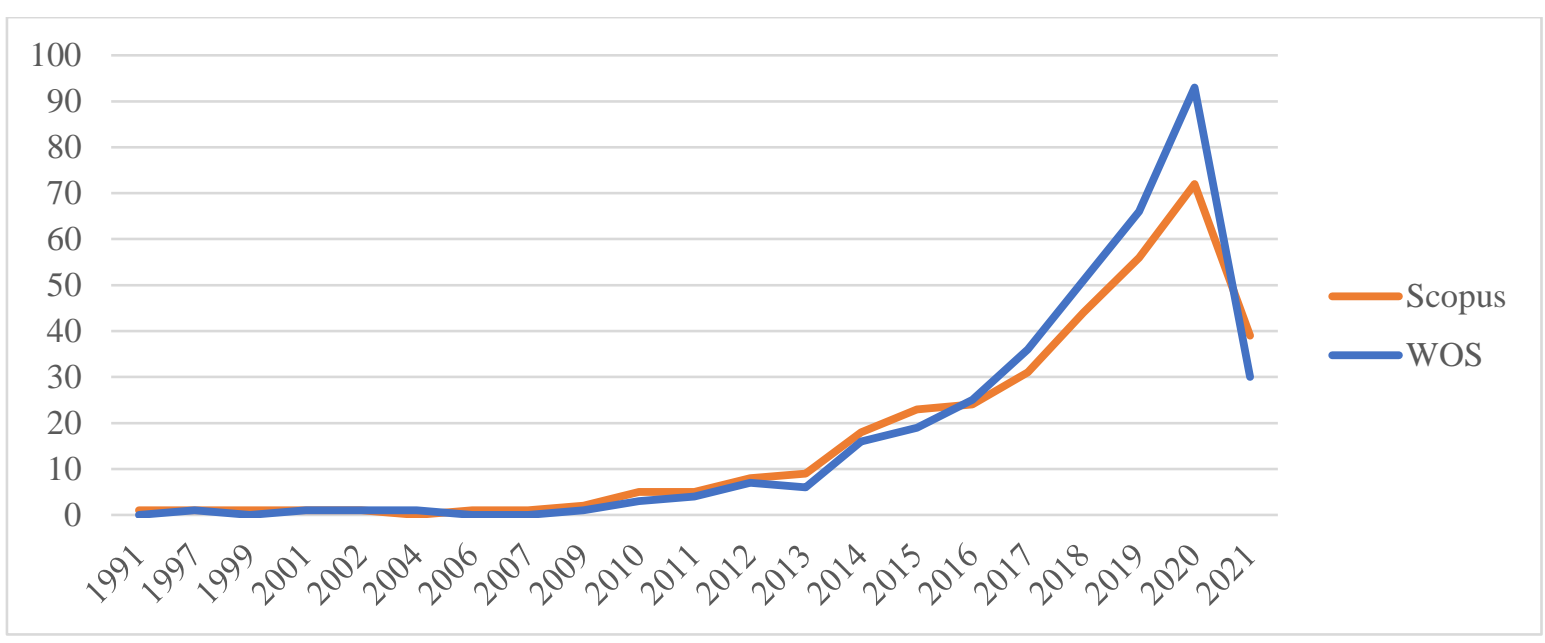

Source: Authors.

Figure 4 shows the list of the most published authors in the area. An asterisk was added to highlight when authors were among the most productive in both databases, with the most significant result maintained. This marking technique was also used in the following analyses. This list indicated which authors serve as the basis for future studies, as they have great interest in the topic. De Belie and Snoeck D. were highlighted for having published the most articles related to this topic. Liu J. had 21 published articles and the subsequent authors all had less than 20 published articles each.

Figure 4. Authors with the most publications.

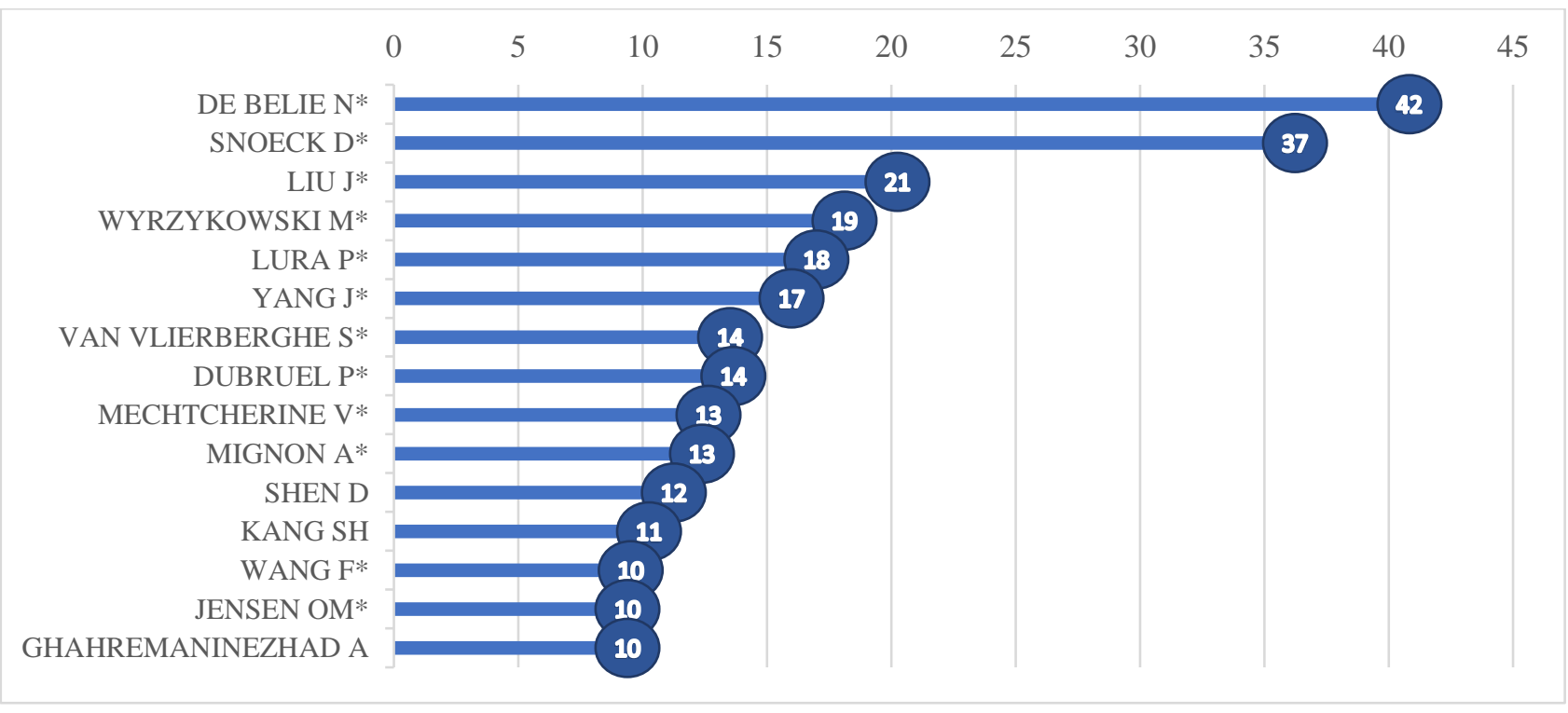

Source: Authors. 
In conjunction with the author analysis, the list of most cited articles (Table 4) shows the most recognized authors and their relevance among other researchers. The articles are listed with the name of the main author, the year of publication, and the abbreviations of the journals. One can see that of the fifteen most cited articles, Jensen OM stood out, since this author was a pioneer in this line of research. Snoek's relevance must be emphasized among the authors. In addition to being the second most productive author, this author had four articles among the fifteen most cited articles. Mechtcherine V. is another author who had more than one article among the most cited articles.

Table 4. Most Cited Works.

\begin{tabular}{lc}
\hline \multicolumn{1}{c}{ Paper } & Total Citations \\
\hline JENSEN OM, 2001, CEM CONCR RES & 641 \\
\hline JENSEN OM, 2002, CEM CONCR RES & 373 \\
\hline SCHRFL C, 2012, CEM CONCR RES & 221 \\
\hline SNOECK D, 2014, J INTELL MATER SYST STRUCT & 207 \\
\hline JUSTS J, 2015, CEM CONCR RES & 190 \\
\hline WANG JY, 2014, CONSTR BUILD MATER & 176 \\
\hline PLANK J, 2015, CEM CONCR RES & 167 \\
\hline SNOECK D, 2015, CEM CONCR RES & 139 \\
\hline SNOECK D, 2014, CONSTR BUILD MATER & 138 \\
\hline SNOECK D, 2012, CEM CONCR RES & 135 \\
\hline HASHOLT MT, 2012, CONSTR BUILD MATER & 126 \\
\hline ESTEVES LP, 2011, THERMOCHIM ACTA & 116 \\
\hline MECHTCHERINE V, 2015, CEM CONCR RES & 113 \\
\hline MECHTCHERINE V, 2014, MATER STRUCT & 108 \\
\hline LEE HXD, 2010, ADV APPL CERAM & 105 \\
\hline
\end{tabular}

Source: Authors.

Figure 5 shows the 15 keywords that were most frequently used by authors to define their articles, and one can note that most authors dealt with concrete as opposed to mortar. These keywords also show the most correlated topics with PAS in cementitious compounds, like curing, shrinkage, compressive stress, internal curing, and autogenous shrinkage. One can see that these terms are useful and complementary when dealing with these polymers in this scenario. 
Figure 5. Most Relevant Words.

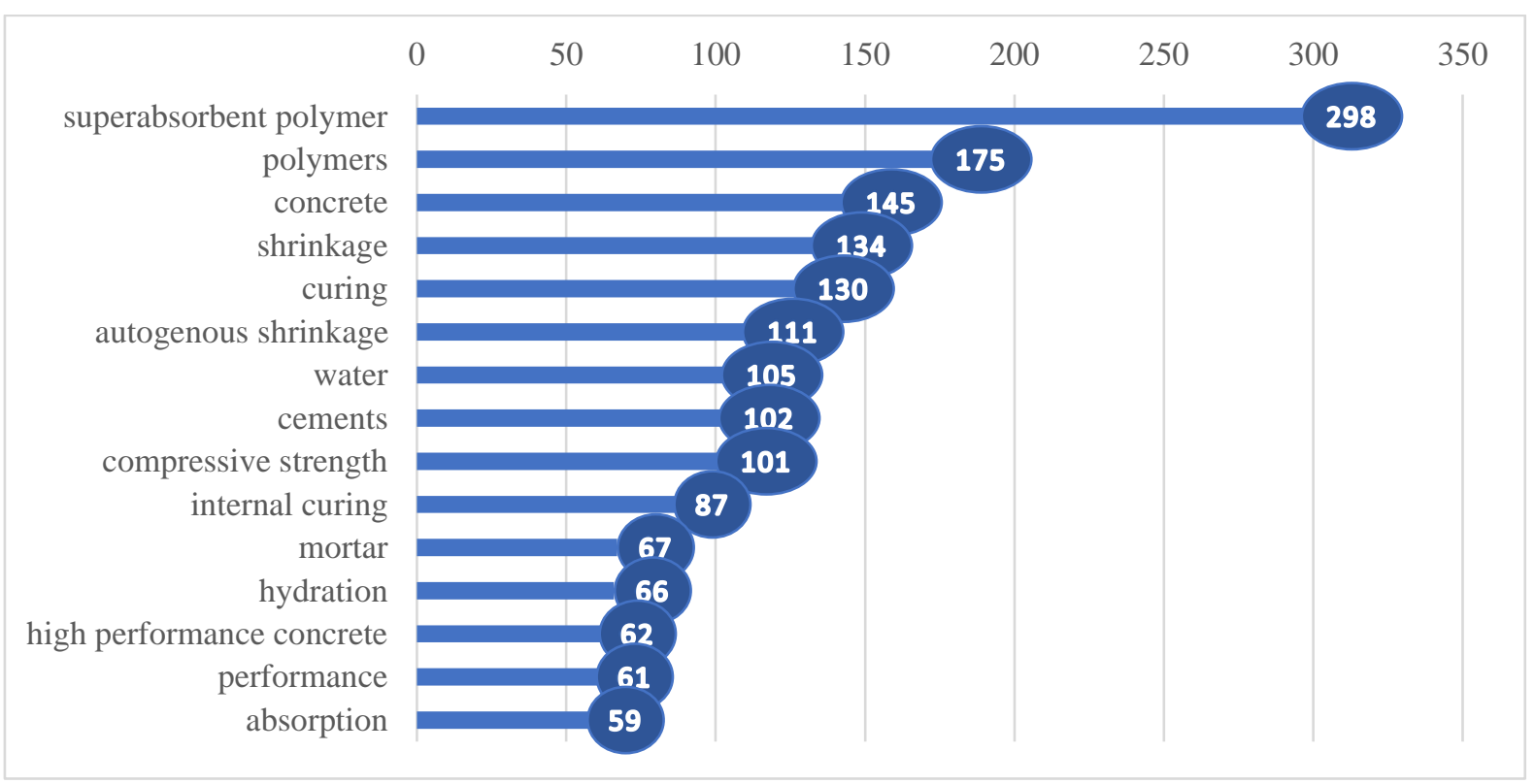

Source: Authors.

Table 5 shows the most relevant periodicals for the research theme, which were measured via volume of publications over the years. They serve as a starting point for searching articles, and display the most prominent lines of research in the area, i.e., they published many studies, allowing one to identify particular needs and to define new targets for conducting future studies. The Construction and Building Materials journal should be highlighted relative to other journals because it published 106 articles, three of which were among the most cited works. Cement and Concrete Research was most prominent in this regard, publishing eight of the most relevant articles.

Table 5. Most relevant periodicals.

\begin{tabular}{lc}
\hline \multicolumn{1}{c}{ Sources } & Articles \\
\hline CONSTRUCTION AND BUILDING MATERIALS & 106 \\
\hline CEMENT AND CONCRETE RESEARCH & 34 \\
\hline CEMENT AND CONCRETE COMPOSITES & 27 \\
\hline MATERIALS & 23 \\
\hline MATERIALS AND STRUCTURES & 22 \\
\hline JOURNAL OF MATERIALS IN CIVIL ENGINEERING & 10 \\
\hline JOURNAL OF BUILDING MATERIALS & 8 \\
\hline JOURNAL OF THE CHINESE CERAMIC SOCIETY & 7 \\
\hline ACI MATERIALS JOURNAL & 6 \\
\hline ADVANCES IN MATERIALS SCIENCE AND ENGINEERING & 9 \\
\hline
\end{tabular}

Source: Authors.

A comparison of the countries with the most published articles, and the most citations, is shown in Table 6. China and Belgium stand out, as they were not only among the top three published countries, but are also among the top three most cited countries, i.e., these countries produce top quality articles within the scientific community. Brazil, the Netherlands, Japan, and India were all among the most published countries, but did not show relevance in terms of the number of citations. Brazil was ranked 18th in number of citations. The opposite was true of Iran, South Africa, Latvia and Poland, which were more cited, even with fewer published articles. Denmark, jumped to second place in terms of number of citations, due to Jensen OM, who was a forerunner in this field. 
Table 6. Comparison of the countries with the most published articles, and the most citations.

\begin{tabular}{cc}
\hline More publication & More citation \\
\hline China & Belgium \\
\hline Belgium & Denmark \\
\hline USA & China \\
\hline South Korea & Germany \\
\hline Switzerland & Switzerland \\
\hline Germany & USA \\
\hline Denmark & South Korea \\
\hline Portugal & United Kingdom \\
\hline United Kingdom & Portugal \\
\hline Brazil & Canada \\
\hline Canada & Iran \\
\hline Netherlands & South Africa \\
\hline Japan & Latvia \\
\hline Singapore & Singapore \\
\hline India & Poland \\
\hline
\end{tabular}

Source: Authors.

Figure 6 shows the proportion of the number of citations of the 10 countries analyzed, showing the dominance of Denmark, Belgium, and China.

Figure 6. Proportion of number of citations per country.

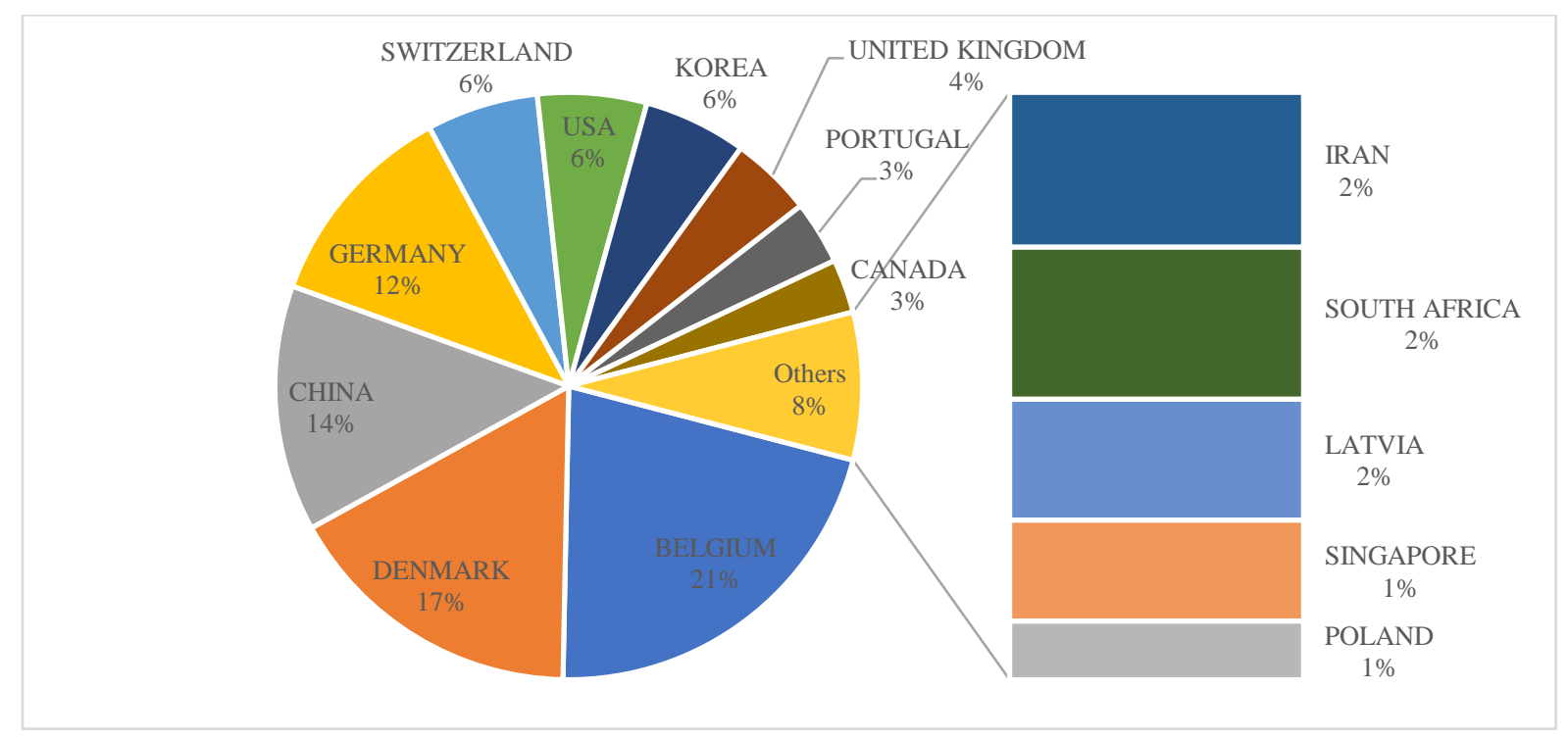

Source: Authors.

Figures 7 and 8, extracted from the Scopus and Web of Science databases, respectively, show that the construction and engineering sectors are the most widely researched areas when it comes to using SAP materials in cementitious composites. Nonetheless, the data show that research is multidisciplinary in its scope, as the theme has been explored by several areas. 
Figure 7. Research areas in the Scopus database.

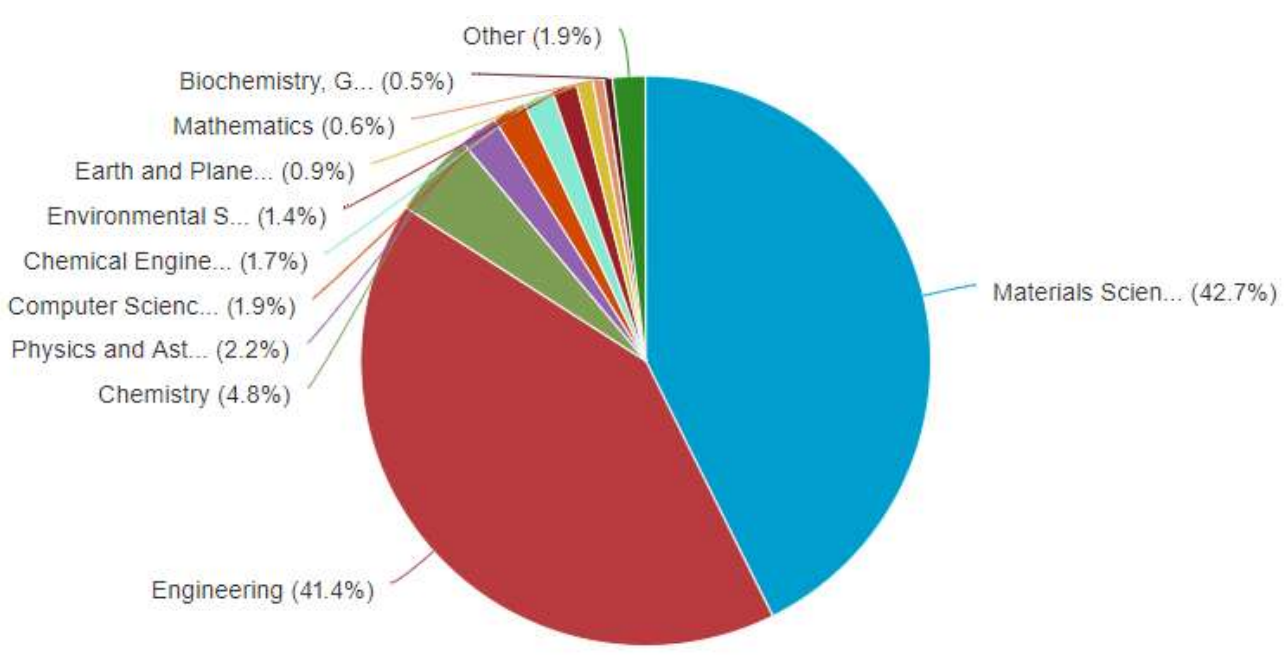

Source: Authors.

Figure 8. Research areas in the Web of Science database.

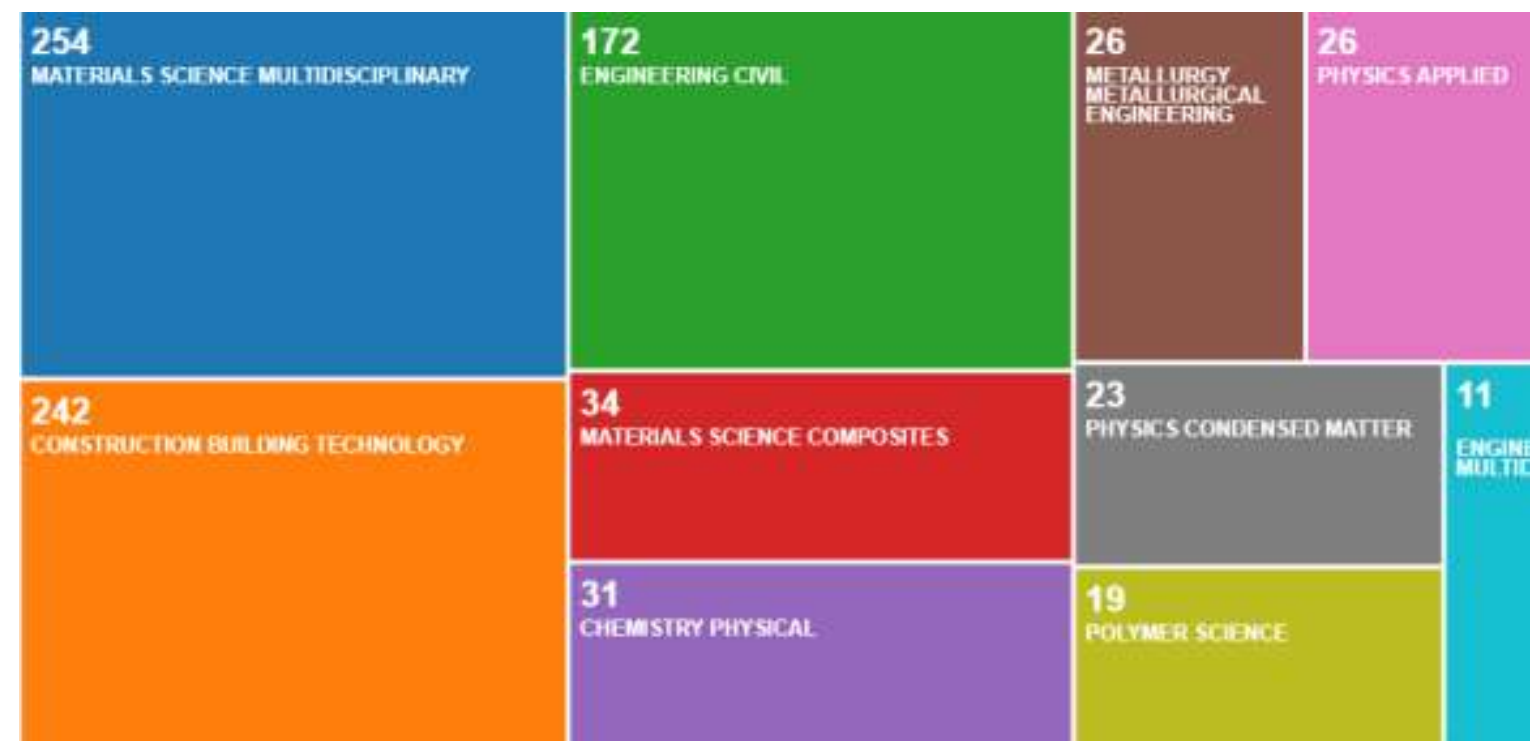

Source: Authors.

Bibliographic coupling per author and document was performed using the VOSviewer software program with data from the Scopus and Web of Science databases. Sizes, proximity among circles, connections, and colors, were all used in the analysis. The greater the proximity and the size of the circles to neighbors, the greater their importance in relation to the same group, which was differentiated by color. Thus, the following figures show groupings per the degree of similarity of citations made in the articles.

The couplings related to the authors, presented in Figures 9 and 10, show the names of some of authors with the most publications (Figure 4), which were De Belie and Snoeck in one group, Wyrzykowski and Lura in another group, and Liu and Yang in a third group, and all these pairs showed relevance among themselves. From the links and groups, one can identify other authors with similar articles with the same focus. Jensen's position must be highlighted in the figures, since the author appears among the groups establishing a relationship with more than one aspect. 
Research, Society and Development, v. 10, n. 4, e171101421818, 2021

(CC BY 4.0) | ISSN 2525-3409 | DOI: http://dx.doi.org/10.33448/rsd-v10i14.21818

Figure 9. Bibliographic Coupling of Authors (Scopus).

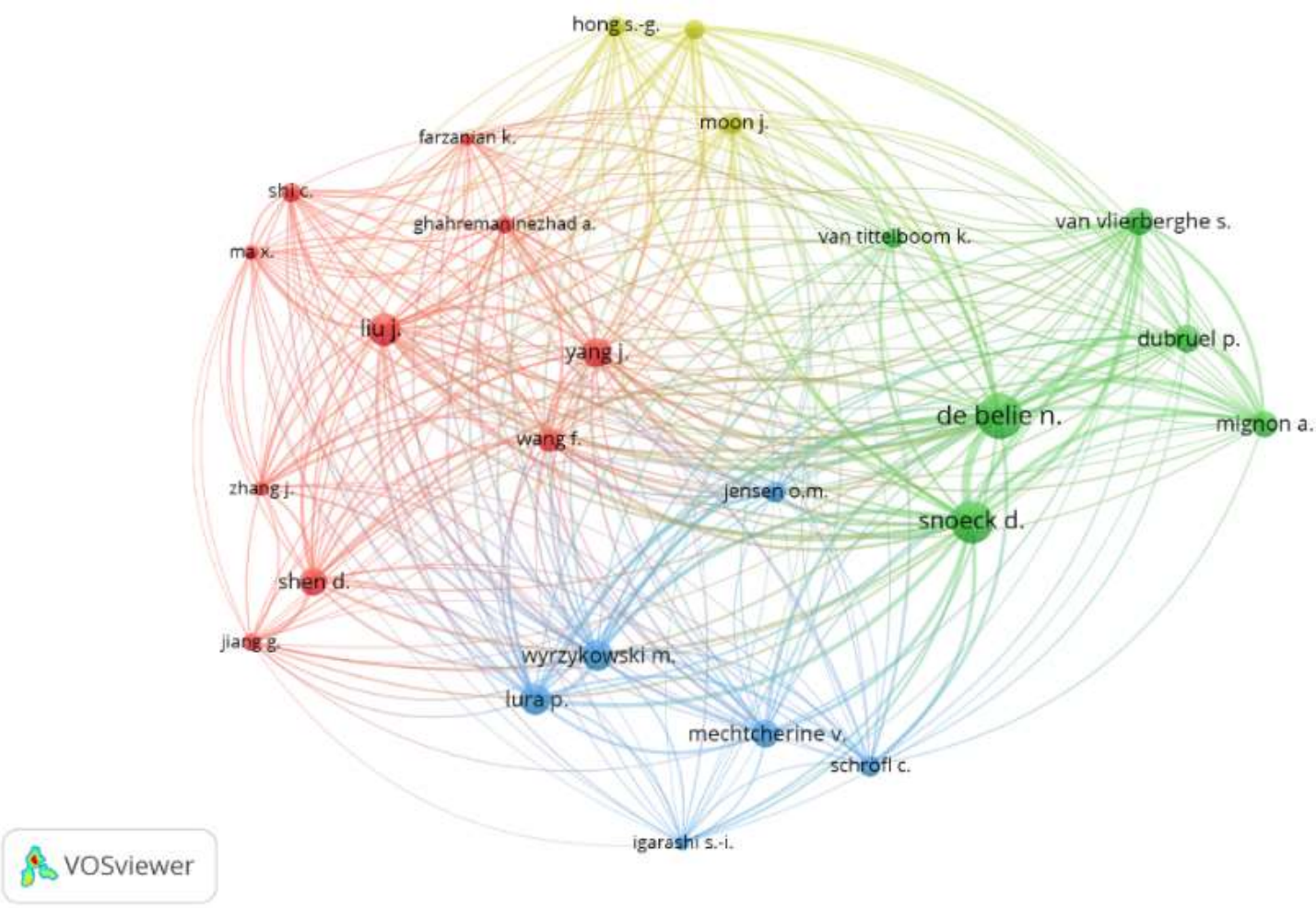

Source: Authors.

Figure 10. Bibliographic Coupling of Authors (WOS).

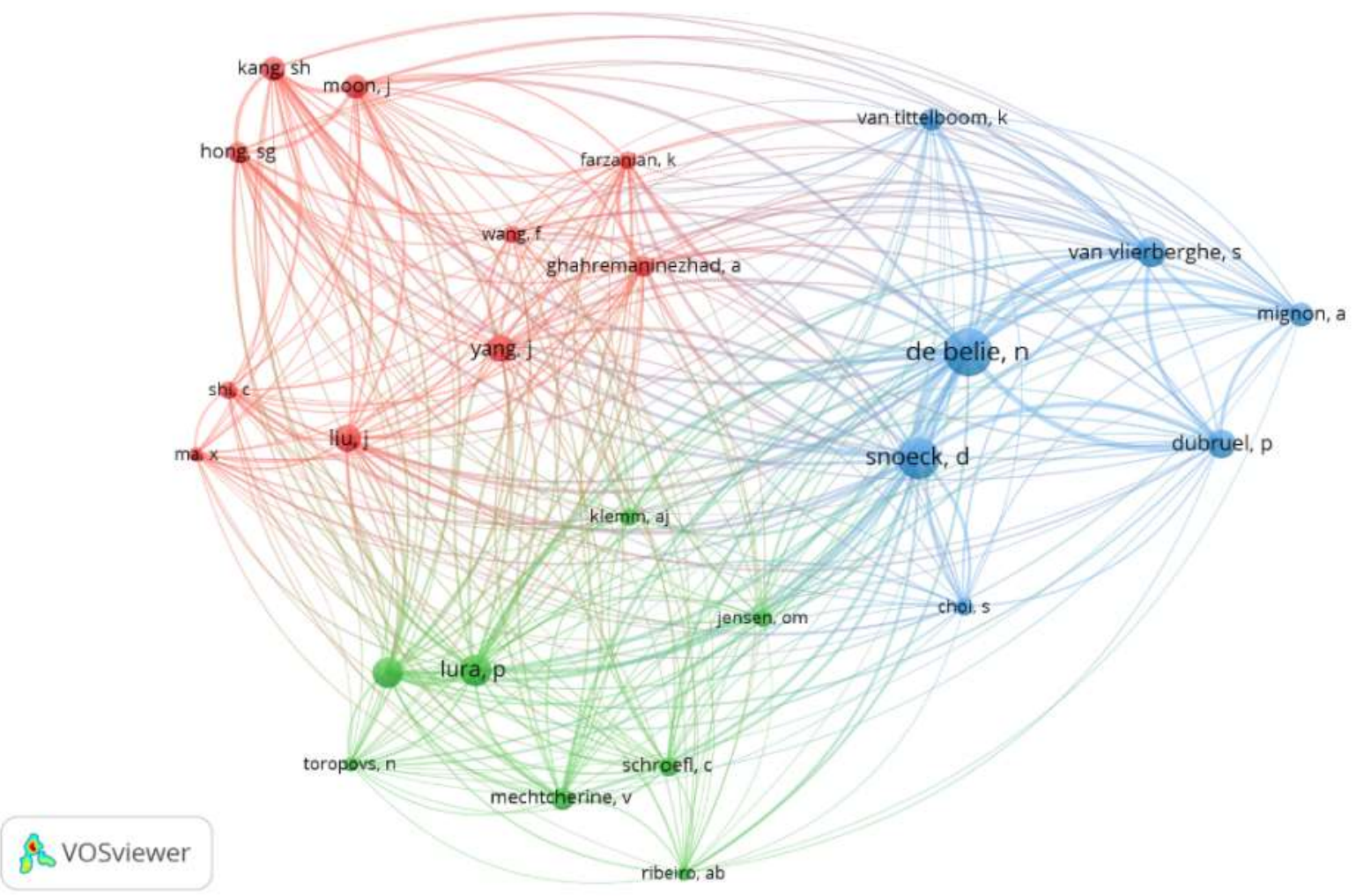

Source: Authors. 
Similarities were observed in the results of the two databases for the couplings conducted using the documents, shown in Figures 11 and 12. Note that the most cited works are present in both analyses. These two figures also illustrate that the documents are divided into 3 large groups, as shown in the author coupling.

Figure 11. Bibliographic Document Coupling (Scopus).

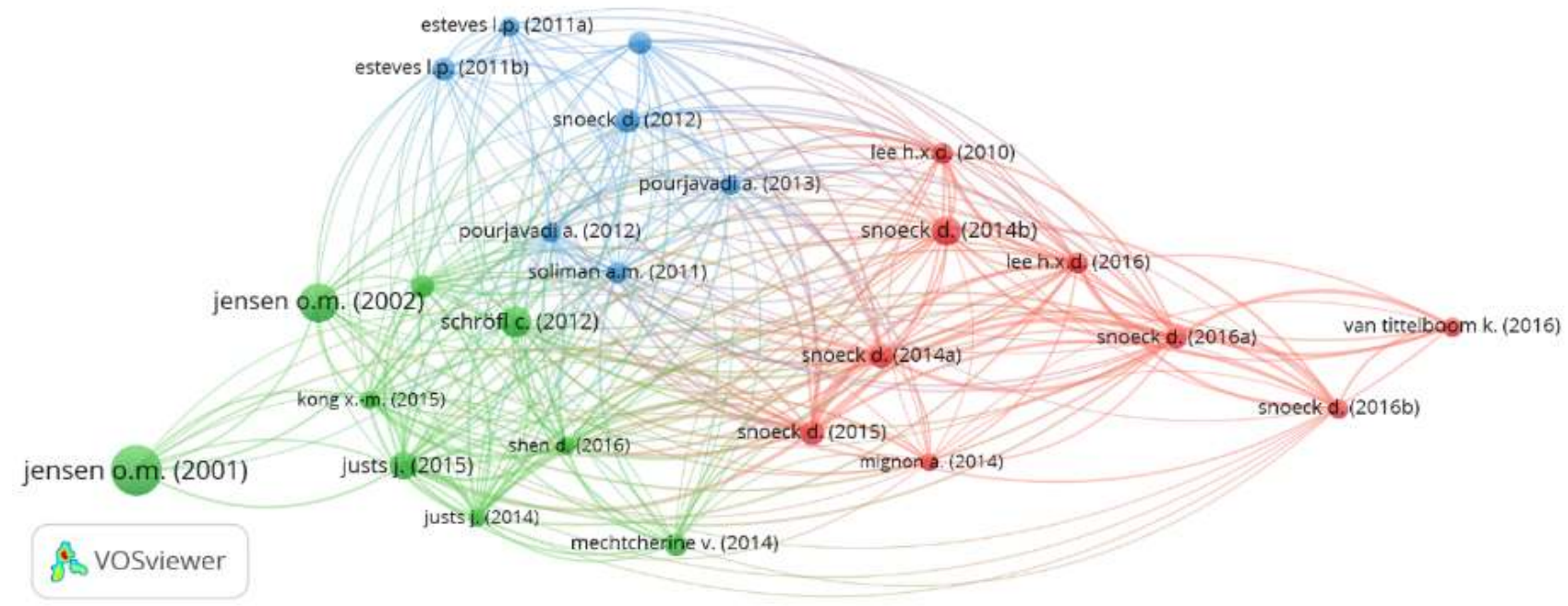

Source: Authors.

Figure 12. Bibliographic Document Coupling (WOS).

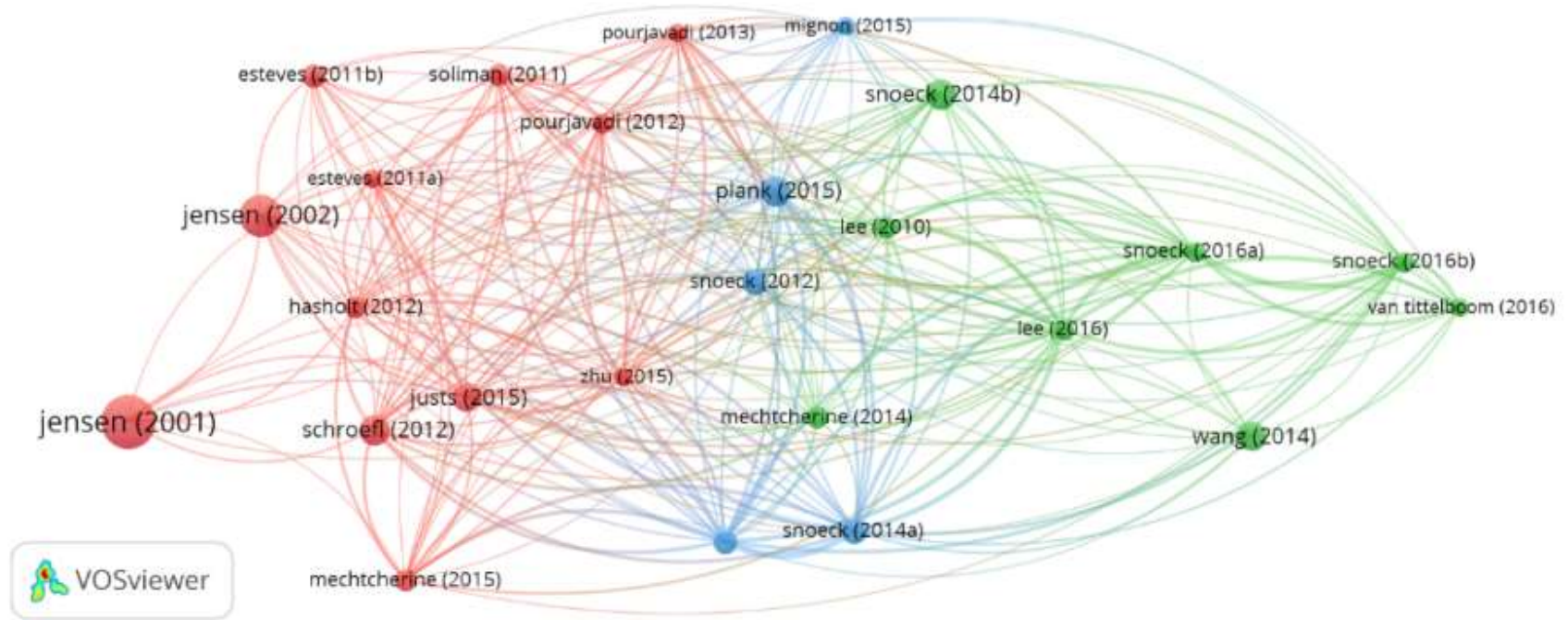

Source: Authors.

Co-citation is the correlation between two articles cited together in a third article. Figures 13 and 14 show the co-citation analysis for the authors, and Figures 15 and 16 show the co-citation analysis for the references in the two databases. These four figures also identify the authors and works referring to Table 4. More relevant groups are shown with different color groups, i.e., the author or article that was most cited by others. 
Research, Society and Development, v. 10, n. 4, e171101421818, 2021

(CC BY 4.0) | ISSN 2525-3409 | DOI: http://dx.doi.org/10.33448/rsd-v10i14.21818

Figure 13. Author Co-citation (Scopus).

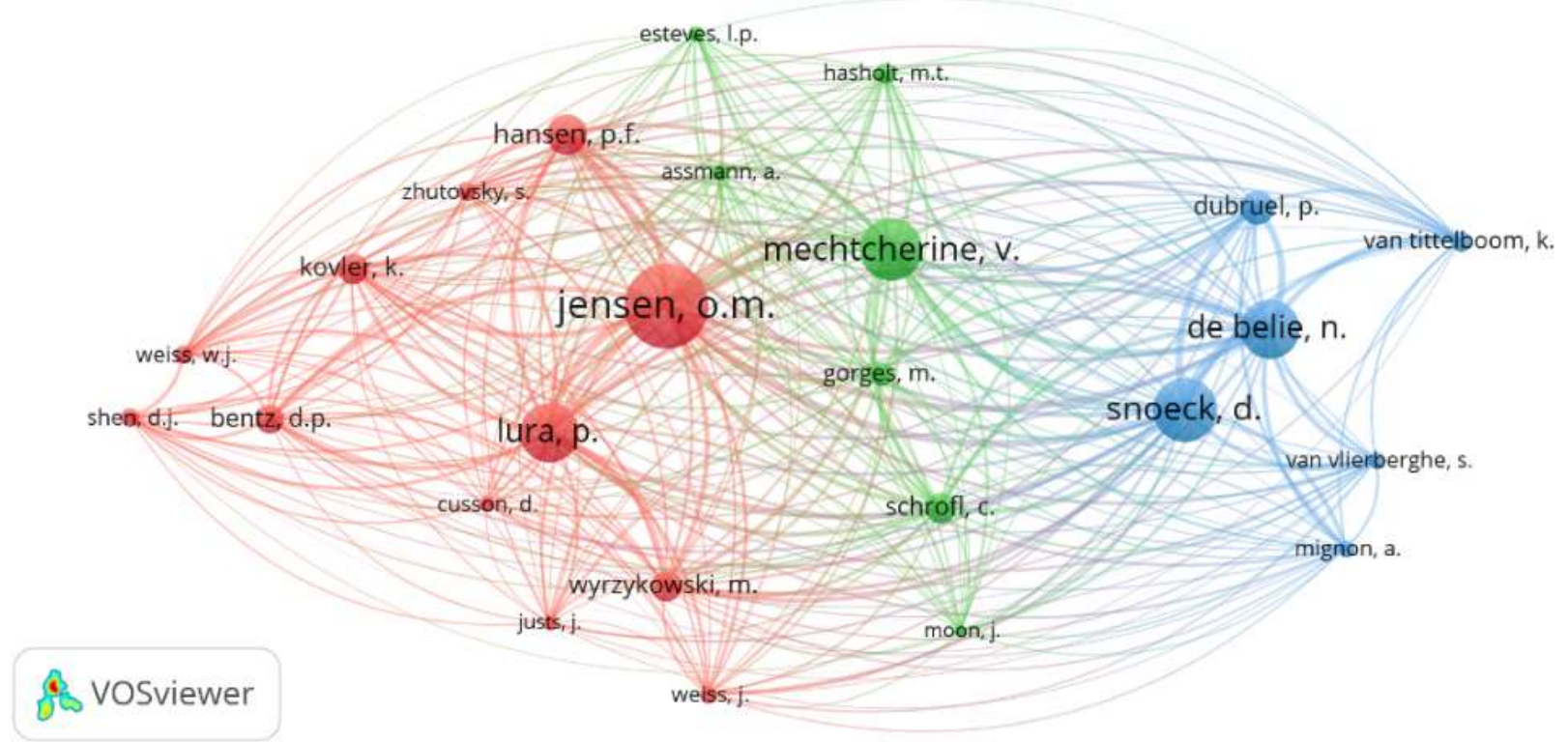

Source: Authors.

Figure 14. Author Co-citation (WOS).

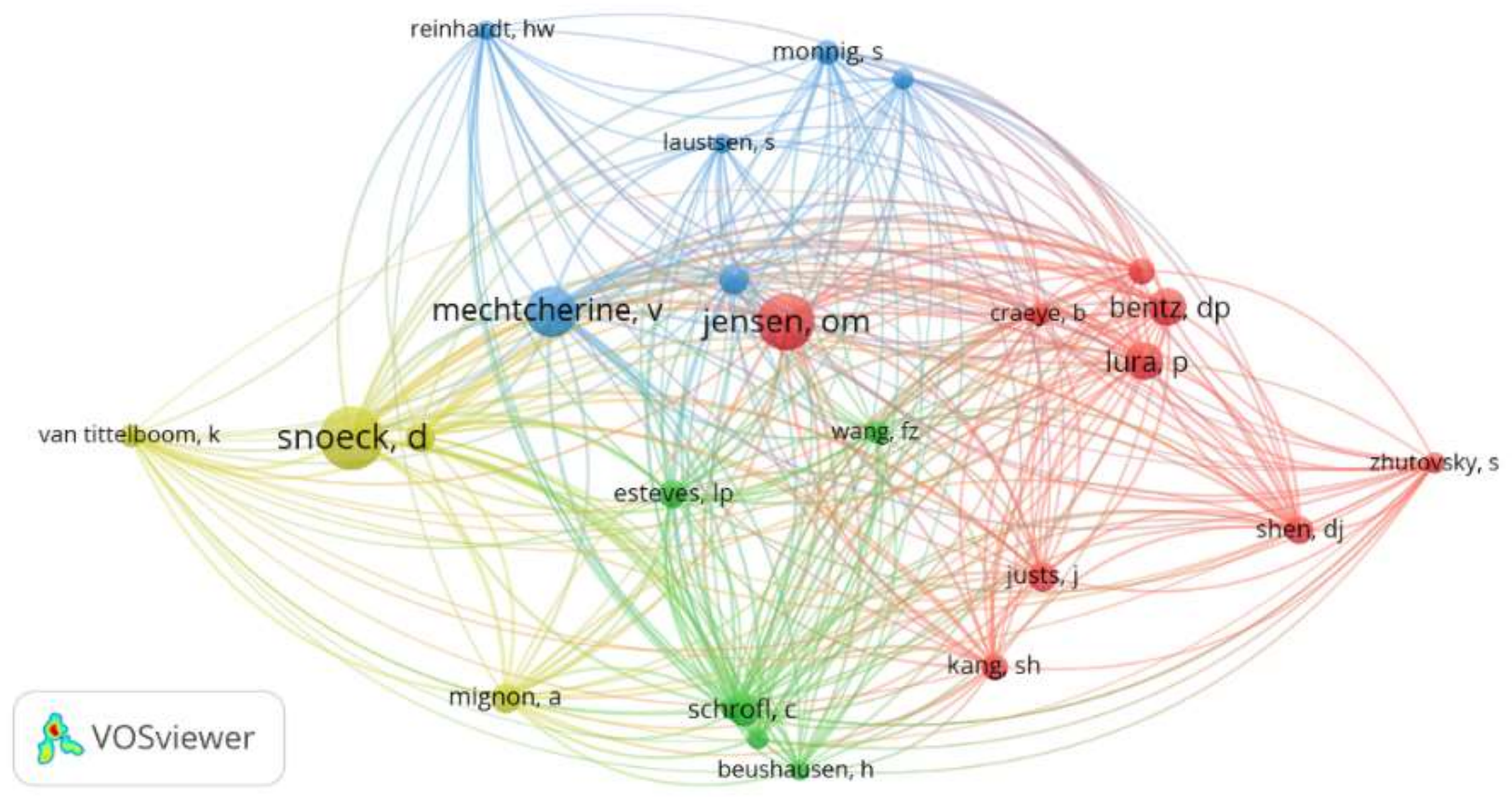

Source: Authors. 
Research, Society and Development, v. 10, n. 4, e171101421818, 2021

(CC BY 4.0) | ISSN 2525-3409 | DOI: http://dx.doi.org/10.33448/rsd-v10i14.21818

Figure 15. Reference Co-citation (Scopus).

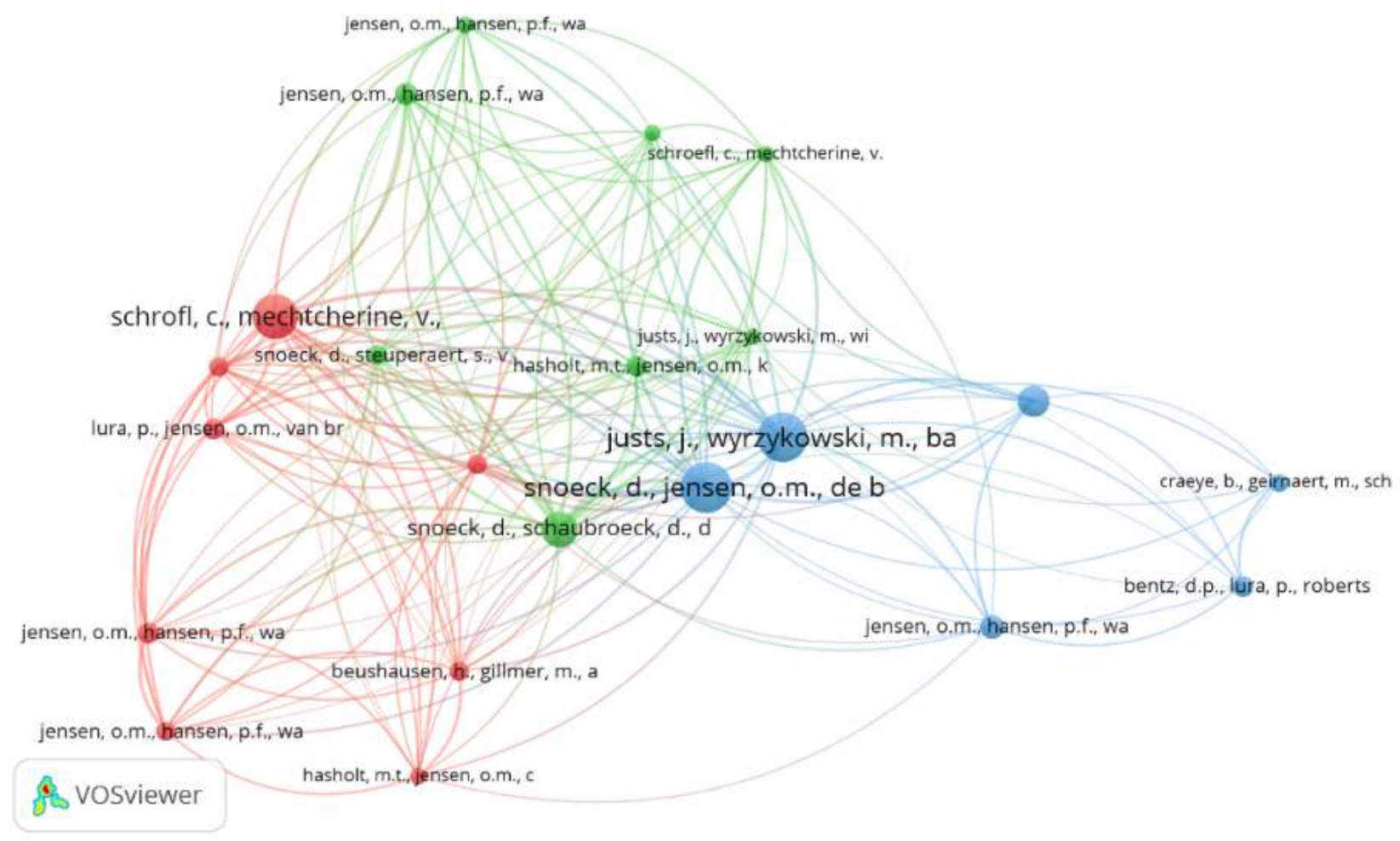

Source: Authors.

Figure 16. Reference Co-citation (WOS).

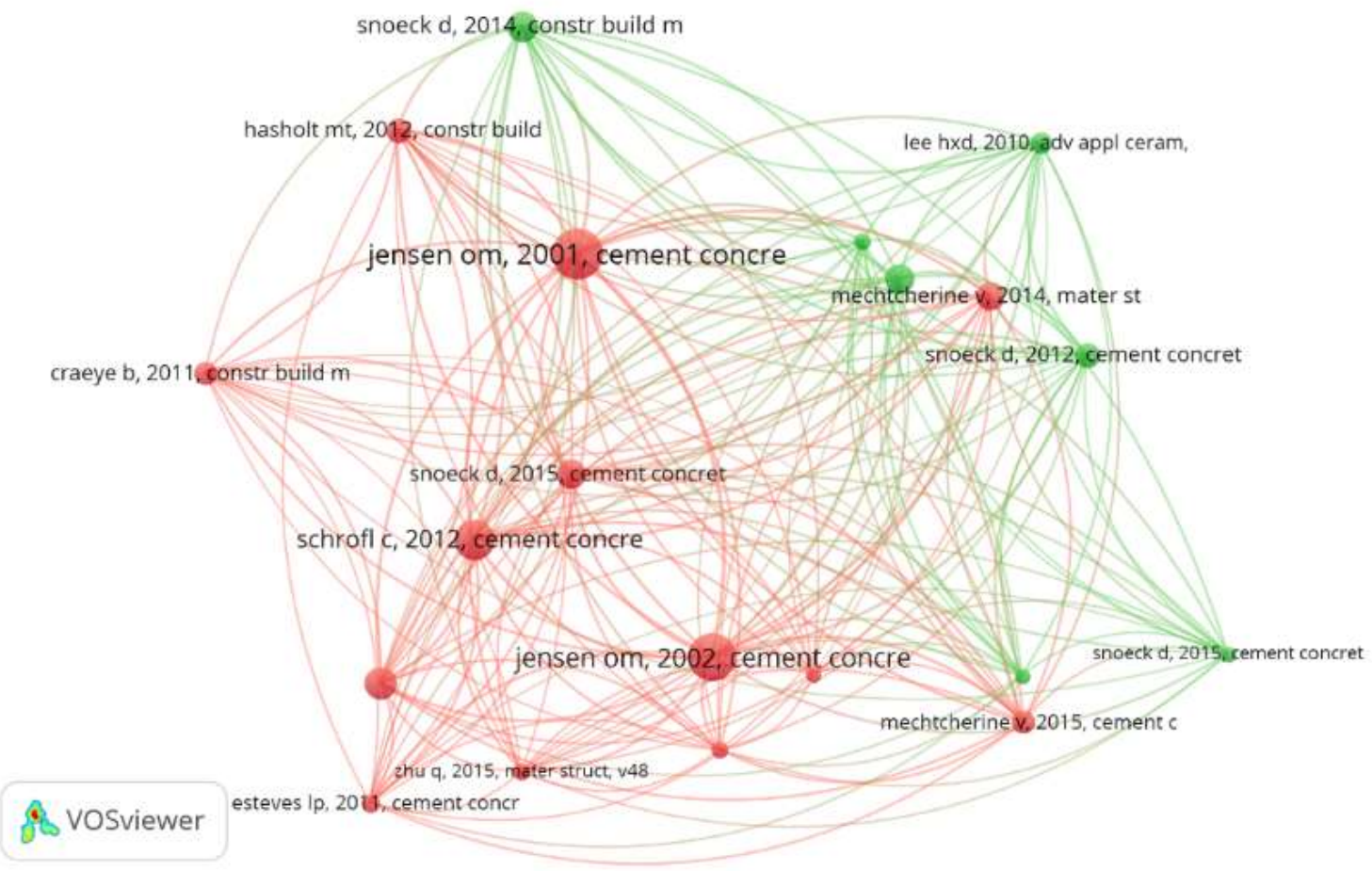

Source: Authors. 


\section{Discussions}

The correlations allowed us to observe affinity more clearly between authors and documents. We observed that (O.M. Jensen \& Hansen, 2001; Ole Mejlhede Jensen \& Hansen, 2002) were the starting points for most articles related to the topic after more deeply analyzing the most prominent articles throughout this study. The first article deals with conceptualizing and setting the theoretical foundation for using SAPs in cement-based materials, which was little explored at the time. The second article describes the experimental observations on the subject, describing that using polymer can control macropore inclusion formations filled with water in concrete, preventing autogenous shrinkage.

In addition to these studies, Jensen published further works with other relevant authors, like Snoeck et al. (2015), where the authors studied reactions of Portland cement pastes with added SAP and compared to pastes with added materials like fly ash, binders, or blast furnace slag. The experiment was successful in showing that shrinkage rates improved in slurries with added polymers as internal curing agents.

De Belie and Snoeck contributed significantly to the topic, and were the first and second most published authors, respectively, in addition to having four articles among the most cited works in the area. The Snoeck et al. (2014), study proved that combined SAP and microfiber elements could be effective for polymers acting as crack sealants, preventing moisture passage and helping mortars self-cure. In a similar study, Snoeck et al. (2012b) measured water penetration in cement-based materials with SAP, using a neutron radiograph. The conclusions showed that capillary crack absorption and permeability were reduced in samples containing SAP particles.

Schröfl et al. (2012) was the third most cited article, which studied the relationship between molecular structures and the efficiency of SAP as an internal curing agent to mitigate autogenous shrinkage in mortars. It was proven that SAP neutralized autogenous shrinkage in the most critical period of cement hydration, i.e., when the most heat is generated.

Justs et al. (2015) is listed in Table 4 as the fifth most cited article in the area, which studied the influence of SAPs in ultra-highperformance concretes. The combination proved to be valid, since it resulted in a delay in the main hydration peak, reducing autogenous shrinkage and relative humidity in the samples.

Hasholt et al. (2012) studied the possible impairment that occurs in compressibility when using SAPs as an internal curing agent to mitigate autogenous shrinkage. The results, however, were inconclusive since the difference between the water/cement ratio in the reference paste and the paste with added SAP made comparison unfeasible.

Lee et al. (2010) investigated using SAPs as concrete crack sealants. The study showed that polymer expansion capacity is linked to alkalinity and the ion content of the solution. The authors found that the flow rate through a slit was substantially reduced with very low amounts of added SAP.

V. Mechtcherine et al. (2014) evaluated the internal curing effects when using SAPs to mitigate autogenous shrinkage, and ascertained other properties on fine particle size in high-performance concretes. The results were consistent, showing that concrete had a considerable decrease in autogenous shrinkage. In Viktor Mechtcherine et al. (2015), the effects of SAPs on the rheological properties of cement mortars were studied. The authors showed that the water to binder ratio, the superplasticizer and silica fume dosages all had impacts.

Esteves (2011) investigated using SAPs with silica fume in cement pastes, which were analyzed using X-ray diffraction (DXR), differential thermal analysis (DTA), and thermograviometric analysis techniques (TGA). The authors observed the internal curing promoted by these additions, which resulted in intensified cement reagent hydration. 


\section{Conclusions}

One can see via the analysis conducted for the articles obtained from the Scopus and Web of Science databases that this research topic has gained attention over time, and that most studies were published in the last five years.

The results of this study showed that:

- De Bilie, Snoeck, and Liu J. were the most published authors, while Jensen, Schrofl and Snoeck, were the most cited authors, who discussed using SAPs in cement-based materials.

- The most cited articles serve as the theoretical basis for the topic, so they deserve the most attention.

- The three most relevant journals for the field are Construction and Building Materials, Cement and Concrete Research and Cement and Concrete Composites. Construction and Building Materials published the most research on the subject.

- The keywords "shrinkage", "autogenous shrinkage" and "internal curing", show the areas that relate most to the theme. These keywords serve as a starting point for new studies that seek to improve upon what has already been presented, and focus on aspects that have been little explored up to this point.

- The countries with the most publications were China, Belgium and the United States, respectively. The countries with the most citations were Belgium, Denmark and China, respectively. Brazil came in tenth place with respect to number of publications in this area, but was little cited by other researchers around the world, with few relevant articles.

- The construction and engineering research areas had the most articles related to the research topic in the databases, yet the publications were related to many other areas as well, reinforcing the fact that multidisciplinary studies can bring together knowledge from different areas.

The main research topic was autogenous shrinkage, but SAP applications in cement-based materials are wide ranging, and some studies focused on mitigating shrinkage during the drying phase, some on the polymer's ability to promote self-curing in concrete, while other studies focused on treating the permeability of cementitious compounds. Literature reviews can produce relevant results on any area of research. They allow researchers to identify theoretical foundations on a specific area of knowledge, and to decide what new research could address, by establishing a connection with relevant existing literature.

This study points to a favorable scenario for other researchers that might seek to study this topic to improve upon preexisting research, since most research is still in the preliminary stages. This topic also points to an increasing research trend, given the versatility of SAPs applied in a wide array of cement-based compounds that still have been little explored, e.g., self-compacting concretes or studies that analyze the thermal behavior of cementitious compounds with added SAP.

\section{References}

Al-Hubboubi, S., Al-Attar, T., Al-Badry, H., Abood, S., Mohammed, R., \& Haddhood, B. (2018). Performance of super-absorbent polymer as an internal curing agent for self-compacting concrete. MATEC Web of Conferences, 162(5), 3-7. https://doi.org/10.1051/matecconf/201816202023

Bentz, B. Y. D. P., Lura, P., \& Roberts, J. W. (2005). Mixture Proportioning for Internal Curing. February, 35-40. https://concrete.nist.gov/ bentz/Mixpropfin/CI2702Bentz.pdf

Esteves, L. P. (2011). Superabsorbent polymers: On their interaction with water and pore fluid. Cement and Concrete Composites, 33(7), 717-724. https://doi.org/10.1016/j.cemconcomp.2011.04.006

Garfield, E. (2001). From Bibliographic Coupling to Co-Citation Analysis via Algorithmic Historio-Bibliography: A Citationist ${ }^{\text {ee }}$ T Tribute to Belver C. Griffith. Drexel University, 45. http://garfield.library.upenn.edu/papers/drexelbelvergriffith92001.pdf

Grácio, M. C. C. (2016). Acoplamento bibliográfico e análise de cocitação: revisão teórico-conceitual. Encontros Bibli: Revista Eletrônica de Biblioteconomia e Ciência Da Informação, 21(47), 82. https://doi.org/10.5007/1518-2924.2016v21n47p82

Guo, Y., Zhang, P., Ding, H., \& Le, C. (2020). Experimental study on the permeability of SAP modified concrete. Materials, 13(15), 1-15. https://doi.org/10.3390/ma13153368

Hasholt, M. T., Jensen, O. M., Kovler, K., \& Zhutovsky, S. (2012). Can superabsorent polymers mitigate autogenous shrinkage of internally cured concrete without compromising the strength? Construction and Building Materials, 31, 226-230. https://doi.org/10.1016/j.conbuildmat.2011.12.062

Jensen, O.M., \& Hansen, P. F. (2001). Water-entrained cement-based materials - I. Principles and theoretical background. Cement and Concrete Research, 31(4), 647-654. https://doi.org/10.1016/S0008-8846(01)00463-X

Jensen, Ole Mejlhede, \& Hansen, P. F. (2002). Water-entrained cement-based materials. Cement and Concrete Research, 32(6), 973-978. https://doi.org/10.1016/S0008-8846(02)00737-8 
Jensen, Ole Mejlhede, \& Lura, P. (2006). Techniques and materials for internal water curing of concrete. Materials and Structures/Materiaux et Constructions, 39(9), 817-825. https://doi.org/10.1617/s11527-006-9136-6

Justs, J., Wyrzykowski, M., Bajare, D., \& Lura, P. (2015). Internal curing by superabsorbent polymers in ultra-high performance concrete. Cement and Concrete Research, 76, 82-90. https://doi.org/https://doi.org/10.1016/j.cemconres.2015.05.005

Lee, H. X. D., Wong, H. S., \& Buenfeld, N. R. (2010). Potential of superabsorbent polymer for self-sealing cracks in concrete. Advances in Applied Ceramics, 109(5), 296-302. https://doi.org/10.1179/174367609X459559

Manzano, M. A. R., da Silva, E. F., Lopes, A. N. M., \& Filho, R. D. T. (2021). Actuating mechanism of superabsorbent polymers as internal curing agents to mitigate autogenous shrinkage in high strength concrete (Hsc) - state of the art . Revista Materia, 26(2). https://doi.org/10.1590/S1517-707620210002.1256

Mechtcherine, V., Gorges, M., Schroefl, C., Assmann, A., Brameshuber, W., Ribeiro, A. B., Cusson, D., Custódio, J., Da Silva, E. F., Ichimiya, K., Ye, G., \& Zhutovsky, S. (2014). Effect of internal curing by using superabsorbent polymers (SAP) on autogenous shrinkage and other properties of a high-performance fine-grained concrete: Results of a RILEM round-robin test. Materials and Structures/Materiaux et Constructions, 47(3), 541-562. https://doi.org/10.1617/s11527-013-0078-5

Mechtcherine, V., Snoeck, D., Schröfl, C., De Belie, N., Klemm, A. J., Ichimiya, K., Moon, J., Wyrzykowski, M., Lura, P., Toropovs, N., Reinhardt, H. W., \& Falikman, V. (2018). Testing superabsorbent polymer (SAP) sorption properties prior to implementation in concrete: results of a RILEM Round-Robin Test. Materials and Structures/Materiaux et Constructions, 51(1). https://doi.org/10.1617/s11527-018-1149-4

Mechtcherine, Viktor, Secrieru, E., \& Schröfl, C. (2015). Effect of superabsorbent polymers (SAPs) on rheological properties of fresh cement-based mortars - Development of yield stress and plastic viscosity over time. Cement and Concrete Research, 67, 52-65.

https://doi.org/https://doi.org/10.1016/j.cemconres.2014.07.003

Ribeiro, V. A. dos S., Werdine, D., Barbosa, L. F., Oliveira, A. F., Barbosa, A. M., Silva, L. R. R., \& Ribeiro, L. H. (2021). Investigação das propriedades físicas e mecânicas do concreto convencional com substituição parcial da areia pelas fibras de bambu. Research, Society and Development, 10(13), e268101321092. https://doi.org/10.33448/rsd-v10i13.21092

Rodrigues, F., Valle, S., Cesar, P., Gabriela, M., \& Ranieri, A. (2022). Use of recycled aggregates from civil construction in self- compacting mortar. Rev. IBRACON Estrut. Mater, 15(1), 1-13.

Sandison, A. (1989). Documentation note: thinking about citation analysis. Journal of Documentation, 45(1), 59-64. https://doi.org/10.1108/eb026839

Schroefl, C., Mechtcherine, V., Gorges, M., Schröfl, C., Mechtcherine, V., Gorges, M., Schrofl, C., Mechtcherine, V., \& Gorges, M. (2012). Relation between the molecular structure and the efficiency of superabsorbent polymers (SAP) as concrete admixture to mitigate autogenous shrinkage. Cement and Concrete Research, 42(6), 865-873. https://doi.org/10.1016/j.cemconres.2012.03.011

Schröfl, C., Mechtcherine, V., \& Gorges, M. (2012). Relation between the molecular structure and the efficiency of superabsorbent polymers (SAP) as concrete admixture to mitigate autogenous shrinkage. Cement and Concrete Research, 42(6), 865-873. https://doi.org/10.1016/j.cemconres.2012.03.011

Shim, Y., Hong, G., \& Choi, S. (2018). Autogenous healing of early-age cementitious materials incorporating superabsorbent polymers exposed to wet/dry cycles. Materials, 11(12). https://doi.org/10.3390/ma11122476

Snoeck, D., \& De Belie, N. (2016). Repeated autogenous healing in strain-hardening cementitious composites by using superabsorbent polymers. Journal of Materials in Civil Engineering, 28(1). https://doi.org/10.1061/(ASCE)MT.1943-5533.0001360

Snoeck, D., Jensen, O. M., \& De Belie, N. (2015). The influence of superabsorbent polymers on the autogenous shrinkage properties of cement pastes with supplementary cementitious materials. Cement and Concrete Research, 74, 59-67. https://doi.org/10.1016/j.cemconres.2015.03.020

Snoeck, D., Steuperaert, S., Van Tittelboom, K., Dubruel, P., \& De Belie, N. (2012a). Visualization of water penetration in cementitious materials with superabsorbent polymers by means of neutron radiography. Cement and Concrete Research, 42(8), 1113-1121. https://doi.org/https://doi.org/10.1016/j.cemconres.2012.05.005

Snoeck, D., Steuperaert, S., Van Tittelboom, K., Dubruel, P., \& De Belie, N. (2012b). Visualization of water penetration in cementitious materials with superabsorbent polymers by means of neutron radiography. Cement and Concrete Research, 42(8), 1113-1121. https://doi.org/10.1016/j.cemconres.2012.05.005

Snoeck, D., Van Tittelboom, K., Steuperaert, S., Dubruel, P., \& De Belie, N. (2014). Self-healing cementitious materials by the combination of microfibres and superabsorbent polymers. Journal of Intelligent Material Systems and Structures, 25(1), 13-24. https://doi.org/10.1177/1045389X12438623

Treinta, F. T., Filho, J. R. F., Sant'Anna, A. P., \& Rabelo, L. M. (1983). Bibliometric studies of research collaboration: A review. Journal of Information Science, 6(1), 33-38. https://doi.org/10.1177/016555158300600105

Treinta, F. T., Filho, J. R. F., Sant'Anna, A. P., \& Rabelo, L. M. (2014). Methodology of bibliographical research using multicriteria decision-making methods. Producao, 24(3), 508-520. https://doi.org/10.1590/S0103-65132013005000078

Vanti, N. A. P. (2002). Da bibliometria à webometria: uma exploração conceitual dos mecanismos utilizados para medir o registro da informação e a difusão do conhecimento. Ciência Da Informação, 31(2), 152-162. https://doi.org/10.3233/WOR-192975

Wyrzykowski, M., Lura, P., Pesavento, F., \& Gawin, D. (2011). Modeling of internal curing in maturing mortar. Cement and Concrete Research, 41(12), 1349-1356. https://doi.org/10.1016/j.cemconres.2011.04.013 